\title{
ANTIOXIDANT AND ANTIMICROBIAL POTENTIAL OF NEW AZETIDIN-2-ONE OF FERULIC ACID
}

\author{
MARIA DRĂGAN ${ }^{1 \#}$, OANA DRAGOSTIN ${ }^{2 \#}$, ANDREEA IACOB ${ }^{1 \#}$, LENUŢA PROFIRE $^{1 \#}$, \\ CĂTĂLINA DANIELA STAN ${ }^{1 *}$, CRISTINA TUCHILUS ${ }^{3}$ \\ ${ }^{I}$ Faculty of Pharmacy, "Grigore T. Popa" University of Medicine and Pharmacy, 16 Universităţii Street, 700115, Iaşi, România \\ ${ }^{2}$ Faculty of Medicine and Pharmacy, "Dunărea de Jos" University, 35 Al. I. Cuza Street, 800216, Galaţi, România \\ ${ }^{3}$ Faculty of Medicine, "Grigore T. Popa” University of Medicine and Pharmacy, 16 Universităţii Street, 700115, Iaşi, România
}

*corresponding author: catalinastan68@yahoo.com

\#Authors with equal contribution

Manuscript received: May 2019

\begin{abstract}
The objective of our study was to evaluate the antioxidant and antimicrobial potential for six new azetidin-2-one derivatives of ferulic acid. The in vitro antioxidant potential of the compounds was assessed by using the total antioxidant capacity and total reducing power assays. The antimicrobial activity was investigated using Gram positive bacteria (Staphylococcus aureus ATCC 25923), Gram negative bacteria (Escherichia coli ATCC 25922, Pseudomonas aeruginosa ATCC 27853) and pathogenic yeast (Candida albicans ATCC 90028, Candida parapsilosis ATCC 22019). Several of the synthesized compounds showed a good antioxidant activity, exceeding the ferulic acid antioxidant potential. All the investigated compounds proved active against Gram positive bacteria.
\end{abstract}

\section{Rezumat}

Obiectivul studiului a constat în evaluarea activităţii antioxidante şi antimicrobiene pentru derivaţii de azetidin-2-onă ai acidului ferulic. S-a evaluat potenţialul antioxidant in vitro al compuşilor prin determinarea capacităţii totale antioxidante şi determinarea puterii reducătoare. Activitatea antimicrobiană a fost studiată utilizând bacterii Gram pozitive (Staphylococcus aureus ATCC 25923), bacterii Gram negative (Escherichia coli ATCC 25922, Pseudomonas aeruginosa ATCC 27853) şi drojdii patogene (Candida albicans ATCC 90028, Candida parapsilosis ATCC 22019). Câţiva dintre compuşii sintetizaţi au prezentat o acţiune antioxidantă mai bună decât a acidului ferulic. În ceea ce priveşte acţiunea antimicrobiană, toate probele au fost active pe speciile Gram pozitive testate.

Keywords: azetidin-2-one, ferulic acid, antioxidant activity, antimicrobial activity

\section{Introduction}

An important risk factor in the pathogenesis of several chronic diseases is the oxidative stress involving free radicals [22]. Chemically synthesized antioxidants and secondary metabolites from plants are widely used in practice for their ability to trap free radicals $[8,10,12,16]$.

Ferulic acid and its derivatives have proven a powerful antioxidant activity in response to free radicals, acting synergistically with other antioxidants. Due to its structure, ferulic acid presents the ability to interrupt the propagation of free radical chain reactions, provide attack sites for free radicals and ensure protection against lipid peroxidation $[8,9$, $17,18]$.

On the other hand, the $\beta$-lactam heterocycles are substances which drew attention and interest of scientists for their potent antibacterial activity [1]. Presently, the research in this area is stimulated due to the development of bacterial resistance to the $\beta$ - lactam antibiotics. Therefore, novel functionalized $\beta$-lactams are being explored [7, 9, 15]. The new interest has been focused on the synthesis and modification of $\beta$-lactam ring in order to obtain new derivatives with diverse biological activities.

Since cyclic amide (lactam) have similar structure with vitamin $\mathrm{C}$, which is a cyclic ester (lactone), it would be challenging to study the antioxidant properties and also the antimicrobial properties of some derivatives which includes in their structure this lactam heterocycle.

Hence, the aim of this study was to investigate the six new azetidin-2-one derivatives of ferulic acid for their antioxidant and antimicrobial activity.

\section{Materials and Methods}

Chemistry. The structure of the tested compounds, azetidin-2-one derivatives of ferulic acid, is presented in Table I. 


\section{Table I}

Azetidin-2-one derivatives of ferulic acid (1a-f)

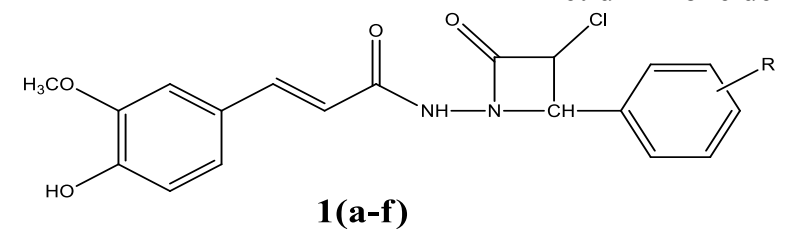

\begin{tabular}{|c|c|c|c|}
\hline Compound & $-\mathbf{R}$ & Compound & -R \\
\hline $\mathbf{1 a}$ & $-\mathrm{H}$ & $\mathbf{1 d}$ & $-\mathrm{NO}_{2}(2)$ \\
\hline $\mathbf{1 b}$ & $-\mathrm{F}(4)$ & $\mathbf{1 e}$ & $-\mathrm{Br}(4)$ \\
\hline $\mathbf{1 c}$ & $-\mathrm{Cl}(4)$ & $\mathbf{1 f}$ & $-\mathrm{OH}(2)$ \\
\hline
\end{tabular}

\section{Antioxidant tests}

All the reagents used for both antioxidant assays were purchased from Sigma Aldrich Company and Fluka Company.

The total antioxidant capacity assay was assessed spectrophotometrically using phosphomolybdenum method [4, 16] with minor modifications. Stock solutions in DMSO $(2 \mathrm{mg} / \mathrm{mL})$ of the samples were obtained. Different volumes $(10 \mu \mathrm{L}, 20 \mu \mathrm{L}, 40 \mu \mathrm{L}$, $60 \mu \mathrm{L}$ ) were measured, completed with DMSO up to $200 \mu \mathrm{L}$ and shacked with $2000 \mu \mathrm{L}$ of reagent solution (0.6M sulfuric acid, $28 \mathrm{mM}$ disodium phosphate and $4 \mathrm{mM}$ ammonium heptamolybdate). The test tubes were incubated at $95^{\circ} \mathrm{C}$ for $90 \mathrm{~min}$. After the cooling process at room temperature the samples were centrifuged at $4600 \mathrm{rpm}$ for $15 \mathrm{~min}$ and the absorbance of the supernatant was measured at $695 \mathrm{~nm}$ using a blank $(200 \mu \mathrm{L}$ DMSO and $2000 \mu \mathrm{L}$ reagent solution) [14]. Ascorbic acid (AA) was used as positive control. The effective concentration $\left(\mathrm{EC}_{50}\right)$ was calculated and expressed in $\mu \mathrm{g} / \mathrm{mL}$. All determinations were performed in triplicate and the values are expressed as mean \pm SD (standard deviation).

The ferric reducing power assay is based on the coloured complex formation between antioxidant compound from the sample and potassium ferricyanide, trichloroacetic acid and ferric chloride $[20,21]$. Stock solutions in DMSO $(2 \mathrm{mg} / \mathrm{mL})$ of the samples were obtained. The aliquots $(1 \mathrm{~mL})$ of different concentrations $(0.25 \mathrm{mg} / \mathrm{mL}, 0.5 \mathrm{mg} / \mathrm{mL}$, $1 \mathrm{mg} / \mathrm{mL}, 2 \mathrm{mg} / \mathrm{mL}$ ) of the compounds, obtained from stock solutions, were added to $1 \mathrm{~mL}$ of sodium phosphate buffer ( $\mathrm{pH} 6.6$ ) and $1 \mathrm{~mL}$ of $1 \%$ potassium ferricyanide. The samples were incubated at $50^{\circ} \mathrm{C}$ for $20 \mathrm{~min}$ and then $1 \mathrm{~mL}$ of $10 \%$ trichloroacetic acid was added. After the centrifugation at $4500 \mathrm{rpm}$ for $15 \mathrm{~min}$ the supernatant $(1 \mathrm{~mL})$ was mixed with $1 \mathrm{~mL}$ of double distilled water and $0.2 \mathrm{~mL}$ of $0.1 \%$ ferric chloride. The absorbance was read at $700 \mathrm{~nm}$ against the blank of the reference to standard (ascorbic acid) [21]. The results were expressed as $\mathrm{EC}_{50}$ values $(\mu \mathrm{g} / \mathrm{mL})$. All determinations were performed in triplicate and the values were expressed as mean \pm SD.

\section{Antimicrobial susceptibility tests}

Microorganisms. It was studied the antimicrobial potential using Gram positive bacteria (Staphylococcus aureus ATCC 25923), Gram negative bacteria (Escherichia coli ATCC 25922, Pseudomonas aeruginosa ATCC 27853) and pathogenic yeasts (Candida albicans ATCC 90028, Candida parapsilosis ATCC 22019).

Disc-diffusion method. The disc-diffusion method (CLSI) was carried out by diluting in sterile $0.9 \%$ $\mathrm{NaCl}$ small amounts of each microbial culture until the turbidity was equivalent to McFarland standard no. $0.5(106 \mathrm{CFU} / \mathrm{mL})$. The obtained suspensions were incorporated in Mueller Hinton agar for bacteria (Oxoid) and in Mueller-Hinton agar for yeasts (Hi Media) in a 1:10 ratio, and then spread on sterile Petri plates ( $25 \mathrm{~mL} /$ Petri plate). Then, $0.1 \mathrm{~mL}$ of each compound were added into sterile stainless steel cylinders ( $5 \mathrm{~mm}$ internal diameter; $10 \mathrm{~mm}$ height), which were applied on the agar surface in Petri plates. As positive controls there were used commercially available discs of Ciprofloxacin ( $5 \mu \mathrm{g} /$ disc), Fluconazol $(25 \mu \mathrm{g} / \mathrm{disc})$ and Nystatin $(100 \mu \mathrm{g} / \mathrm{disc})$. The plates were incubated at $37^{\circ} \mathrm{C}$ for $24 \mathrm{~h}$ (bacteria) and at $24^{\circ} \mathrm{C}$ for $48 \mathrm{~h}$ (yeasts), after that the diameters of inhibition zones were measured in $\mathrm{mm}$, including the disc size $[3,5,11]$.

Broth microdilution method. The compounds were tested for the Minimum Inhibitory Concentration (MIC) and Minimum Bactericidal Concentration (MBC) against Staphylococcus aureus ATCC 25923. Serial double dilutions of each extract in Mueller Hinton broth (Oxoid) were inoculated with equal volumes of bacterial suspension $\left(10^{6} \mathrm{CFU} / \mathrm{mL}\right)$. The lowest concentration of extract for which the complete inhibition of visible growth was observed after $24 \mathrm{~h}$ incubation at $37^{\circ} \mathrm{C}$, represents the MIC. In order to established the $\mathrm{MBC}$ values $0.01 \mathrm{~mL}$ of samples showing complete inhibition of visible growth on the surface of an agar plate were incubated $24 \mathrm{~h}$ at $35^{\circ} \mathrm{C}$. The lowest concentration of extracts required to kill more than $99.9 \%$ of tested microorganisms represents the $\mathrm{MBC}[6,11]$. 


\section{Results and Discussion}

Total antioxidant capacity. Wishing to understand how different moieties have an effect on the antioxidant properties and the structure-activity relationship of different substituents, a series of new azetidin-2-one derivatives of ferulic acid (1a-1f) were investigated. The lactam ring may be responsible for enhancing the free radical scavenging activity. The results revealed that the newly synthesised compounds showed a greater antioxidant activity at low concentrations as compared to ferulic acid. The $\mathrm{EC}_{50}$ values of the tested compounds are presented in Table II. A low
$\mathrm{EC}_{50}$ value indicates a higher total antioxidant capacity [16]. Good antioxidant activity showed the compounds resulting from the condensation reaction with 4chlorobenzaldehyde 1c $\left(\mathrm{EC}_{50}=19.67 \pm 0.07 \mu \mathrm{g} / \mathrm{mL}\right)$, 2-nitrobenzaldehyde 1d $\left(\mathrm{EC}_{50}=19.89 \pm 0.05 \mu \mathrm{g} / \mathrm{mL}\right)$, 4-fluorobenzaldehyde $\mathbf{1 b}\left(\mathrm{EC}_{50}=20.007 \pm 0.03\right.$ $\mu \mathrm{g} / \mathrm{mL})$ and 2-hydroxybenzaldehyde 1f $\left(\mathrm{EC}_{50}=\right.$ $23.004 \pm 0.06 \mu \mathrm{g} / \mathrm{mL})$. These compounds are about 1.4 to 1.2 times more active than ferulic acid $\left(\mathrm{EC}_{50}=\right.$ $27.62 \pm 0.05 \mu \mathrm{g} / \mathrm{mL}$ ) at the same concentration and so the results support the initial premise.

Total antioxidant capacity $\left(\mathrm{EC}_{50}, \mu \mathrm{g} / \mathrm{mL}\right)$ of the ferulic acid azetidin-2-one derivatives $(\mathbf{1 a - f})$

\begin{tabular}{|c|c|c|c|c|c|}
\hline Comp. & $\mathbf{E C}_{\mathbf{5 0}} \boldsymbol{\mu g} / \mathbf{m L}$ & Comp. & $\mathbf{E C}_{\mathbf{5 0}} \boldsymbol{\mu} \mathbf{~ g / m L}$ & Comp. & $\mathbf{E C}_{\mathbf{5 0}} \boldsymbol{\mu g} / \mathbf{m L}$ \\
\hline $\mathbf{1 a}$ & $31.55 \pm 0.06$ & $\mathbf{1 d}$ & $19.89 \pm 0.05$ & $\mathbf{F A}$ & $27.62 \pm 0.05$ \\
\hline $\mathbf{1 b}$ & $20.01 \pm 0.03$ & $\mathbf{1 e}$ & $39.30 \pm 0.03$ & $\mathbf{A A}$ & $5.16 \pm 0.05$ \\
\hline $\mathbf{1 c}$ & $19.67 \pm 0.07$ & $\mathbf{1 f}$ & $23.00 \pm 0.06$ & & \\
\hline
\end{tabular}

FA - ferulic acid; AA - ascorbic acid; Data represent mean \pm SD $(n=3, p<0.05)$

Ferric reducing power. The analysis of the results, presented in Table III, which are expressed as effective concentration $50\left(\mathrm{EC}_{50}\right)$, showed that the structural modulation of ferulic acid by obtaining the corresponding azetidine-2-one resulted mostly in the intensification of the ferric reducing power of ferulic acid. A small $\mathrm{EC}_{50}$ value indicated a higher reducing power [16]. Based on the structure activity relationships, it is indicated that the presence of substitution on the ferulic acid molecule and on the side chain phenyl ring influences the antioxidant potency of the molecule. The most active compounds were $1 \mathbf{a}\left(\mathrm{EC}_{50}=25.08 \pm\right.$ $0.03 \mu \mathrm{g} / \mathrm{mL})$, 1 e $\left(\mathrm{EC}_{50}=26.71 \pm 0.3 \mu \mathrm{g} / \mathrm{mL}\right)$, 1c $\left(\mathrm{EC}_{50}=27.61 \pm 0.05 \mu \mathrm{g} / \mathrm{mL}\right)$ and $\mathbf{1 b}\left(\mathrm{EC}_{50}=34.83 \pm\right.$ $0.02 \mu \mathrm{g} / \mathrm{mL})$, the compounds being 1.52 to 1.1 times more active than ferulic acid $\left(\mathrm{EC}_{50}=38.32 \pm 0.05\right.$ $\mu \mathrm{g} / \mathrm{mL})$.

Table III

Ferric reducing power $\left(\mathrm{EC}_{50}, \mu \mathrm{g} / \mathrm{mL}\right)$ of the ferulic acid azetidin-2-one derivatives (1a-f)

\begin{tabular}{|c|c|c|c|c|c|}
\hline Comp. & $\mathbf{E C}_{\mathbf{5 0}} \boldsymbol{\mu g} / \mathbf{m L}$ & Comp. & $\mathbf{E C}_{\mathbf{5 0}} \boldsymbol{\mu g} / \mathbf{m L}$ & Comp. & $\mathbf{E C}_{\mathbf{5 0}} \mathbf{\mu g} / \mathbf{m L}$ \\
\hline $\mathbf{1 a}$ & $25.08 \pm 0.03$ & $\mathbf{1 d}$ & $43.86 \pm 0.06$ & $\mathbf{F A}$ & $38.32 \pm 0.05$ \\
\hline $\mathbf{1 b}$ & $34.83 \pm 0.02$ & $\mathbf{1 e}$ & $26.71 \pm 0.02$ & $\mathbf{A A}$ & $5.16 \pm 0.01$ \\
\hline $\mathbf{1 c}$ & $27.61 \pm 0.05$ & $\mathbf{1 f}$ & $66.94 \pm 0.03$ & & \\
\hline
\end{tabular}

FA - ferulic acid; AA - ascorbic acid; Data represent mean \pm SD $(n=3, p<0.05)$

Table IV

Antibacterial and antifungal activities of the ferulic acid azetidin-2-one derivatives (1a-f)

\begin{tabular}{|c|c|c|c|c|c|}
\hline \multirow[b]{2}{*}{ Comp. } & \multicolumn{5}{|c|}{ Diameter of inhibition zones (mm) } \\
\hline & $\begin{array}{c}\text { S. aureus } \\
\text { ATCC } 25923\end{array}$ & $\begin{array}{c}\text { E. coli } \\
\text { ATCC } 25922\end{array}$ & $\begin{array}{l}\text { P. aeruginosa } \\
\text { ATCC } 27853\end{array}$ & $\begin{array}{c}\text { C. albicans } \\
\text { ATCC } 90028\end{array}$ & $\begin{array}{l}\text { C. parapsilosis } \\
\text { ATCC } 22019\end{array}$ \\
\hline $1 \mathbf{a}$ & $16.0 \pm 0.00$ & $12.0 \pm 0.00$ & $16.0 \pm 0.00$ & $12.0 \pm 0.00$ & $15.0 \pm 0.00$ \\
\hline $\mathbf{1 b}$ & $15.0 \pm 0.00$ & 0 & 0 & $11.0 \pm 0.00$ & $12.3 \pm 0.57$ \\
\hline $1 \mathrm{c}$ & $13.3 \pm 0.57$ & $10.0 \pm 0.00$ & 0 & $15.0 \pm 0.00$ & $14.0 \pm 0.00$ \\
\hline 1d & $20.3 \pm 0.57$ & $10.0 \pm 0.00$ & $11.0 \pm 0.00$ & $11.0 \pm 0.00$ & $12.3 \pm 0.57$ \\
\hline $1 \mathrm{e}$ & $16.5 \pm 0.50$ & $15.0 \pm 0.00$ & 0 & 0 & $10.5 \pm 0.50$ \\
\hline 1f & $16.0 \pm 0.00$ & $14.0 \pm 0.00$ & 0 & $15.0 \pm 0.00$ & $10.0 \pm 0.00$ \\
\hline Ciprofloxacin $(5 \mu \mathrm{g} / \mathrm{disc})$ & $26.7 \pm 0.06$ & $26.5 \pm 0.50$ & $30.0 \pm 0.00$ & $* \mathrm{NT}$ & $* \mathrm{NT}$ \\
\hline Fluconazol $(25 \mu \mathrm{g} / \mathrm{disc})$ & $\mathrm{NT}^{*}$ & $\mathrm{NT}^{*}$ & $\mathrm{NT}^{*}$ & $18.5 \pm 0.50$ & $18.5 \pm 0.50$ \\
\hline Nystatin $(100 \mu \mathrm{g} / \mathrm{disc})$ & $\mathrm{NT}^{*}$ & $\mathrm{NT}^{*}$ & $\mathrm{NT}^{*}$ & $18.5 \pm 0.50$ & $19.0 \pm 0.00$ \\
\hline
\end{tabular}

*NT-not tested

Antimicrobial activity. In Table IV there are presented the diameters of the inhibition zones (in $\mathrm{mm}$ ) for the tested compounds. The assays were carried out in triplicate and the results are expressed as means \pm SD. A high activity was observed for all samples against Gram positive bacteria. For the compounds reported to have antimicrobial activity in the disc-diffusion method we have determined the MIC and MBC values against $S$. aureus ATCC 25923. The results are showed in Figure 1. 


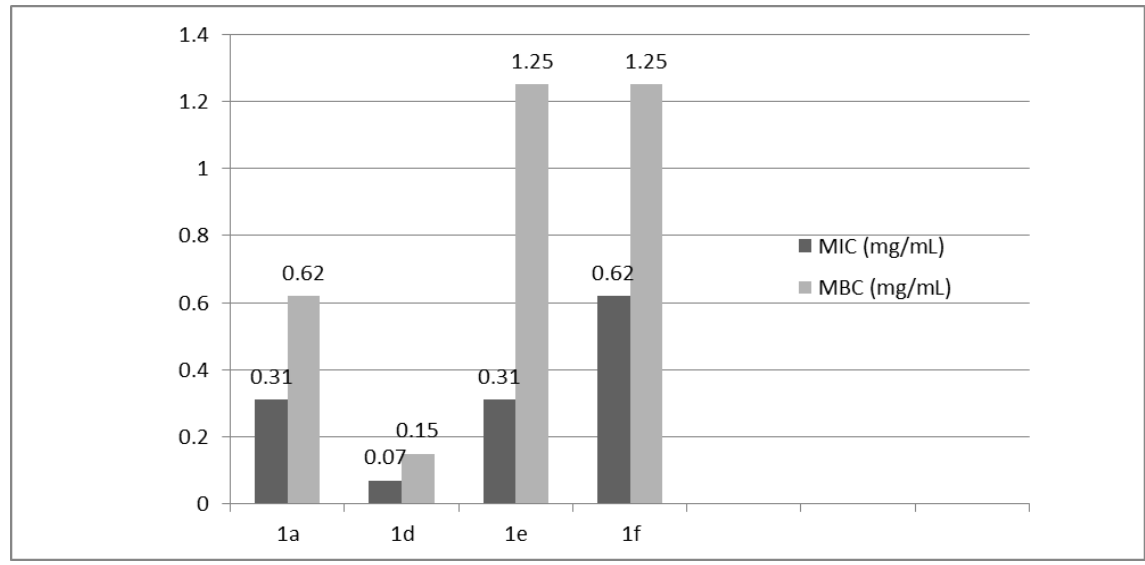

Figure 1.

MIC and MBC values of the ferulic acid azetidin-2-one derivatives against $S$. aureus ATCC 25923

Aiming to develop new systems with antibacterial or antifungal action we studied the antimicrobial activity against Gram positive and Gram negative bacteria and Candida spp. The antimicrobial assays showed an evident difference in terms of antibacterial and antifungal activity, implying that the tested compounds act differently on various types of microorganisms. All new six tested compounds have good antibacterial activity against $S$. aureus ATCC 25923 and medium activity against $E$. coli. The most active compound against $S$. aureus proved to be 1d (2nitrobenzaldehyde) and against E. coli was 1e (4brombenzaldehyde). Against $P$. aeruginosa ATCC 27853 the tested compounds had no activity, except 1 a (H-benzaldehyde) and 1d (2-nitrobenzaldehyde). Also, the tested compounds demonstrated a good activity against the Candida strains, except 1e (4brombenzaldehyde). The obtained results indicate that the new ferulic acid azetidin-2-one derivatives possess good antimicrobial properties. Nevertheless, ferulic acid acts against Gram-positive and Gramnegative bacteria [10] and lactam heterocycles have a potent antibacterial activity on Gram-positive bacteria [1]. The inherent variability and potency in the antimicrobial spectrum among the tested compounds may be explained by including the lactam heterocycle in the ferulic acid molecule and also by adding different substituents on the side chain phenyl ring [19]. In the quantitative assay all the tested compounds showed good MIC values for $S$. aureus. The MBC values for compounds 1a, 1d, 1f were 2 times greater than the MIC values and for compound 1e were 4 times greater.

\section{Conclusions}

Our results indicate that the new six azetidin-2-one derivatives of ferulic acid possess good antioxidant activity at low concentrations and good antimicrobial activity against Gram positive bacteria. While all the investigated compounds present biological activity, the intensity and efficiency depend on the nature of substituents attached to the phenyl ring. Regarding the antioxidant activity, the most active compounds proved to be $1 \mathrm{c}(\mathrm{R}=4-\mathrm{Cl})$ and $1 \mathrm{~b}(\mathrm{R}=4-\mathrm{F})$, these compounds being more actives than ferulic acid in both antioxidant assays.

Considering the antimicrobial activity, the most active compound against $S$. aureus proved to be 1d $\left(\mathrm{R}=2-\mathrm{NO}_{2}\right)$. The investigated derivatives present good in vitro antioxidant and antimicrobial potentials, but in vivo further studies still need to be performed in order to support the initial premise.

\section{Acknowledgement}

This work was financially supported by CNCSISUEFISCDI, Postdoctoral Fellowship Programme PN-II-Human Resources, project number 3/28.07.2010, code PD 149/2010.

\section{References}

1. Arya N, Jagdale AY, Patil TA, Yeramwar SS, Holikatti SS, Dwivedi J, Shishoo CJ, Jain KS, The chemistry and biological potential of azetidin-2ones. Eur J Med Chem., 2014; 74: 619-656.

2. B'Bhatt H, Sharma S, Synthesis and antimicrobial activity of pyrazole nucleus containing 2thioxothiazolidin-4-one derivatives. Arab J Chem., 2017; 10: S1590-S1596.

3. Burlec AF, Cioancă O, Mircea C, Arsene C, Tuchiluş C, Corciovă A, Hăncianu M, Antioxidant and antimicrobial properties of Chrysanthemum and Tagetes selective extracts. Farmacia, 2019; 67(3): 405-410.

4. Cačic M, Molnar M, Sarkanj B, Has-Schon E, Rajkovic V, Synthesis and antioxidant activity of some new coumarinyl-1,3-thiazolidine-4-ones. Molecules, 2010; 15(10): 6795-6809.

5. CLSI, Method for Antifungal Disk Diffusion Susceptibility Testing of Yeasts; Approved Guideline. $2^{\text {nd }}$ Edition. Wayne, PA: Clinical and Laboratory Standards Institute; 2009. 
6. CLSI, Performance standards for antimicrobial susceptibility testing. $27^{\text {th }}$ ed. CLSI supplement M100. Wayne, PA: Clinical and Laboratory Standards Institute; 2017.

7. Dragostin I, Dragostin OM, Drăgan $M$, Stan CD, Zamfir CL, Drug hypersensitivity using encapsulation method with chitosan-ceterizine derivatives. Rev Chim Bucharest, 2018, 69(12): 3731-3735.

8. Drăgan M, Stan CD, Pânzariu A, Profire L, Assessment of in vitro antioxidant and antiinflamatory activities of new azetidin-2-ones derivatives of ferulic acid. Farmacia, 2016; 64(5): 717-721.

9. Hakami AY, Sari Y, $\beta$-Lactamase inhibitor, clavulanic acid, attenuates ethanol intake and increases glial glutamate transporters expression in alcohol preferring rats. Neurosci Lett., 2017; 657: 140-145.

10. Kumar N, Pruthi V, Potential applications of ferulic acid from natural sources. Biotechnol Rep(Amst), 2014; 4: 86-93

11. Khalass S, Popescu C, Popescu IA, Arsene AL, Udeanu DI, Lupuliasa D, Physico-chemical and microbiological characterization of Fagopyrum esculentum Moench fatty oil obtained by cold pressure. Farmacia, 2018; 66(5): 899-903.

12. Liu J, Wen X, Lu J, Kan J, Jin CH, Free radical mediated grafting of chitosan with caffeic and ferulic acids: Structures and antioxidant activity. Int J Biol Macromol., 2014; 65: 97-106.

13. Mircea C, Cioanca O, Bild V, Iancu C, Stan C, Hancianu M, In vivo antioxidant properties of some mushroom extracts in experimentally induced diabetes. Farmacia, 2018; 66(2): 257-261.

14. Pop CE, Pârvu M, Arsene AL, Pârvu AE, Vodnar DC, Tarcea M, Toiu AM, Vlase L, Investigation of antioxidant and antimicrobial potential of some extracts from Hedera helix L. Farmacia, 2017; 65(4): 624-629.
15. Rasras AJM, Al-Tel TH, Al-Aboudi AF, Al-Qawasmeh RA, Synthesis and antimicrobial activity of cholic acid hydrazone analogues. Eur J Med Chem., 2010; 45: 2307-2313.

16. Roy S, Metya SK, Sannigrahi S, Raharnan N, Ahmed F, Treatment with ferulic acid to rats with streptozotocin-induced diabets: effects on oxidative stress, pro-inflammatory cytokines and apoptosis in the pancreatic $\beta$ cell. Endocrine, 2013; 44: 369-379.

17. Sanga Z, Pan W, Wang K, Ma Q, Yu L, Yang Y, Bai P, Leng C, Xu Q, Li X, Tan Z, Liu W, Design, synthesis and evaluation of novel ferulic acid-Oalkylamine derivatives as potential multifunctional agents for the treatment of Alzheimer's disease. Eur J Med Chem., 2017; 130: 379-392.

18. Sangeeta D, Digvijay S, Pradeep TD, Rupesh S, Rahul T, Healing potential of ferulic acid on dermal wound in diabetic animals. Asian J Molec Model., 2015; 1: 1-16.

19. Țântaru G, Marin L, Vieriu M, Panainte AD, Poiată A, Apostu M, Bibire N, The influence of structure on antibacterial activity of some new aniline derived Schiff bases. Rev Chim., 2015; 66(12): 1965-1967.

20. Tătărîngă G, Stan C, Mircea C, Jitareanu A, Zbancioc AM. Antioxidant evaluation of some coumarin derivatives. Farmacia, 2016, 64(4): 533-538.

21. Tătărîngă G, Stan CD, Zbancioc AM, Jitareanu A, Tuchiluş C, Preliminary screening of biological activities of some new Schiff bases of isatins. Farmacia, 2014, 62(1): 14-22.

22. Zduńska K, Agnieszka D, Kolodziejczak A, Rotsztejn $\mathrm{H}$, Antioxidant properties of ferulic acid and its possible application. Skin Pharmacol Physiol., 2018; 31: 332-336 